\title{
Assessing farmers' interest in agroforestry in two contrasting agro-ecological zones of Rwanda
}

\author{
C. Bucagu $\cdot$ B. Vanlauwe $\cdot$ M. T. Van Wijk • \\ K. E. Giller
}

Received: 25 October 2011/Accepted: 23 May 2012/Published online: 8 June 2012

(C) The Author(s) 2012. This article is published with open access at Springerlink.com

\begin{abstract}
Uptake and management of agroforestry technologies differs among farms in Rwanda and needs to be documented as a basis for shaping future research and development programs. The objective of this study was to investigate current agroforestry practices, farmers' preferences, tree management and perspectives for agroforestry technologies. The study consisted of a combination of a formal survey, a participatory tree testing, farmer evaluation and focus group discussions in the Central Plateau (moderate altitude) and the Buberuka (high altitude) agroecological zones. A survey and a tree testing exercise with a range of species: (timber species-Eucalyptus urophyla, Grevillea robusta; legume shrubs - Calliandra calothyrsus, Tephrosia vogelii; and fruit species-Persea americana and Citrus sinensis) were
\end{abstract}

C. Bucagu $(\bowtie) \cdot$ M. T. Van Wijk · K. E. Giller Plant Production Systems, Wageningen University, P.O. Box 430, 6700 AK Wageningen, The Netherlands e-mail: charles.bucagu@wur.nl

C. Bucagu

Department of Crop Science, National University

of Rwanda, P.O. Box 117, Butare, Rwanda

B. Vanlauwe

International Institute of Tropical Agriculture (IITA),

Nairobi, Kenya

M. T. Van Wijk

International Livestock Research Institute (ILRI), Nairobi, Kenya carried out in Simbi (Central Plateau) and Kageyo (Buberuka) with farmers from different wealth status who received tree seedlings for planting, managing, and evaluating. Simbi had more tree species farm ${ }^{-1}$ (4.5) than Kageyo (2.9). Fruit trees occurred most frequently in Simbi. Grevillea robusta, Calliandra calothyrsus and Tephrosia vogelii were mostly established along contours, fruit trees in homefields and Eucalyptus urophyla trees in woodlots. Survival was better on contours for Grevillea robusta (58-100 \%) and Calliandra calothyrsus (50-72 \%). Tree growth was strongly correlated with the total tree lop biomass in Eucalyptus urophyla $\left(R^{2}=0.69\right)$. Grevillea robusta was most preferred in Simbi and Eucalyptus urophyla and Calliandra calothyrsus in Kageyo. The study provided information useful for revising the national agroforestry research and extension agenda and has important implications for other countries in the highlands of Africa.

Keywords Tree species - Biophysical factors · Farmer resource groups · Tree testing · Farmer evaluation

\section{Introduction}

Agroforestry is an ancient practice in sub-Saharan Africa where farmers deliberately retain and integrate trees into their farmland. It was widely promoted as a 
sustainability-enhancing practice combining the benefits of both forestry and agriculture (Bene et al. 1977). Agroforestry development has taken place in subSaharan African as a response to the major problems, including food shortage in many parts of the developing world, the increasing ecological degradation and the energy crisis at the beginning of the 1970s (King 1989). In Rwanda, food security and land degradation were the major concerns in the early 1990s due to high population pressure, decreased farm size, land encroachment on forested and steeplysloping landscapes (Ndiaye and Sofranko 1994).

Though agroforestry is a native practice in subSaharan rural communities, the formal research in the discipline started much later. Worldwide agroforestry research spearheaded by ICRAF (International Council for Research in Agroforestry) was firstly directed towards the description and characterisation of the farmers' agroforestry systems (Sanchez 1995) with the objective of identifying major constraints and opportunities for designing of adequate solutions. Later, specific practices including intercropping and integrated farming systems were widely investigated (Wilson and Kang 1981) to mainly deal with soil fertility and livestock concerns in the tropics. Agroforestry systems were developed with specific tree species such as Faidherbia albida that has shown great potential in providing fodder, the ability to fix nitrogen and other services. In Rwanda, integrating legume species within cropping systems was extensively tested using species such as Sesbania sesban, Leuceana leucocephala, Calliandra calothyrsus and Markhamia lutea in bean (Phaseolus vulgaris), potato (Solanum tuberosum), pea (Pisum sativum) and wheat (Triticum sp.) (Yamoah et al. 1989). The principle underlying the promotion of leafy biomass of agroforestry species lies in the fact that the addition of green manure is important in the tropics where most of the plant nutrients are provided from organic matter (Kang et al. 1981). The most remarkable effect of legume shrubs in livestock production was that related to the use of legume species such as Calliandra for milk production (Paterson et al. 1998, Wambugu et al. 2011). Alongside these benefits, agroforestry could supply other basic services including firewood, food, medicine, fodder, timber, boundary markers and windbreaks (Young 1997; Franzel et al. 2002). In most agroforestry trials undertaken in the 1990s, priority was on the investigation of the performance of different species under different biophysical conditions (Nair 1998). Later agroforestry research has been broadened to include social, anthropological, environmental and economic concepts (Mercer and Miller 1998).

Despite major agroforestry development and achievements in the last two decades, it is important to notice that most of agroforestry species promoted by the research are not necessarily the ones widely adopted by smallholder farmers in sub-Saharan Africa. The uptake of different agroforestry technologies varies across farms and each species seems to be managed as a unique technology in countries such as Rwanda. It appears that farmers design individual systems that respond to their multiple needs depending on the available resources, making the agroforestry systems complex in their arrangement over time and space.

Several authors have recognized that smallholder farmers in the tropics operate under diverse agroecological conditions (Tittonell et al. 2005; Niang and Styger 1990) and within an agro-ecological zone, farm management is rarely homogenous. Variability at regional level, mostly related to agro-ecological conditions, and, at farm level, farm management strategies, significantly influence the establishment and productivity of trees and shrubs. Other authors have stressed the importance of both socioeconomic and agro-ecological conditions in the identification of a window of opportunity that favours particular forms of management (Giller et al. 2006).

There is therefore a need to use innovative approaches to identify potential niches for agroforestry species and to apply these to complex smallholder farming systems. A research approach integrating multidimensional socio-economic and ecological aspects could assist in properly identifying 'socio-ecological niches' for agroforestry species (cf. Ojiem et al. 2007). Participatory methods include several techniques, including formal surveys, informal interviews, technology testing and farmer scoring (Raintree 1983; Franzel 2001; De Groote et al. 2010) that would allow speeding up the process of identifying agroforestry technologies appropriate for a specific farming system but these have not been widely applied in Rwanda.

Of the numerous published agroforestry research activities, conducted in Rwanda over the last 20 years (Yamoah and Burleigh 1990; Balasubramanian and Sekayange 1992; Niang et al. 1998; Yamoah et al. 
1989; Balasubramanian and Egli 1986; den Biggelaar and Gold 1995; Pinners and Balasubramanian 1991, Ndiaye and Sofranko 1994), only few have engaged with farmers through the use of participatory research methods.

This study was designed to assess the interest of smallholder farmers in agroforestry technologies in Rwanda. Specifically, the study aimed to: (i) assess the current agroforestry situation by describing the type of tree species, tree density and diversity in the targeted agro-ecological zones, (ii) evaluate the preferred species by farmers on the basis of tree management, growth and productivity; and (iii) identify constraints faced by farmers, farmers' perceptions and perspectives with regards to tree planting in the different locations.

\section{Materials and methods}

Biophysical characteristics of the research sites and socioeconomic characteristics of households

Two agro-ecological zones were compared, namely the Central Plateau (average altitude of 1,500-1,700 m a.s.l and annual rainfall of $1,160 \mathrm{~mm}$ ) and the northern Buberuka highlands (average altitude of 1,800-2,650 $\mathrm{m}$ a.s.l and annual rainfall of $1,560 \mathrm{~mm}$ rainfall) both of which are considered to have good potential for agroforestry (Yamoah et al. 1989). The Central Plateau agro-ecological zone (AEZ) is located in south-west of Rwanda contrasting with the Buberuka highlands agroecological zone (AEZ) located in Northern part of the country. In the Central Plateau, Histosols and Cambisols are dominant in valleys and Cambisols, Acrisols and Leptosols dominant on hills. In the Buberuka highlands, soils are dominated by Cambisols, Nitisols and Leptosols in uphill areas and Histosols and Vertisols in wetland areas (Djimde 1988; Niang and Styger 1990). The Simbi sector was selected in the Central Plateau agro-ecological zone to represent a mixed cropping system with dominance of Phaseolus vulgaris, Manihot esculenta, Zea mays together with coffee (Coffea arabica) as a cash crop. Simbi is located at 1,634 $\mathrm{m}$ a.s.l with an average temperature of $20^{\circ} \mathrm{C}$. Umurera village (164 households, 1,324 inhabitants) was selected as a representative study site. Umurera village shares much of biophysical and socioeconomic variability with the central agro-ecological zone. Information collected through our own measurement or District official documents (Huye DDP 2007) indicate that population density, farm size, cattle ownership and other socio-economic features are comparable to those reported for the Central Plateau AEZ (Verdoodt 2002; Yamoah et al. 1989). Total rainfall averaged 1,061 and 1,044 $\mathrm{mm}$ in 2007 and 2008 respectively. In Buberuka highlands, Kageyo sector was selected to represent the typical farming system with dominance of wheat (Triticum sp.) and Irish potato (Solanum tuberosum). Kageyo is located at $1,736 \mathrm{~m}$ a.s.l with an average temperature of 15-16 ${ }^{\circ} \mathrm{C}$, and average precipitation of 737 and $1,015 \mathrm{~mm}$ in 2007 and 2008, respectively. Mutobo village (94 households, 529 inhabitants) was purposely selected as study site because it has similar biophysical and socioeconomic features found in Buberuka (Gicumbi DDP 2007), be it in terms of population density, land use and most socio-economic indicators. In both locations, the periods from September to October and November to December 2007 season were exceptionally dry (Fig. 1).

In the two locations, wealth ranking allowed categorising local households into classes based on local farmer criteria including land size, the number of cattle, the type of house, the ability of the farmer to hire labour (adapted from Grandin 1988). Four farmer groups were identified: a wealthier farmer group, a moderately resourced farmer group, a poor farmer group and a landless farmer group. Wealthier farmers accounted for 2-7\% of the households, moderate farmers $8-30 \%$, poor farmers $66-84 \%$ and landless farmers $1-2 \%$. The landless farmer group was not included in the study due to the fact that they had no land which they manage on their own. Table 1 gives an overview of the main socioeconomic characteristics of households at the two sites.

Inventory of current trees grown on farms

Before starting the inventory exercise, it was important to clearly define what "a tree" is. In an earlier study, a tree was defined differently depending on whether one uses the western or the Rwandan epistemology (den Biggelaar 1994). From the definition given by Kagame (1958 cited in den Biggelaar 1994) the term "tree" is understood as all plants that are not grasses (referred to as Rwandan-Bantu epistemology). The definition clearly differs from the western conception of a "tree" that only encompasses 


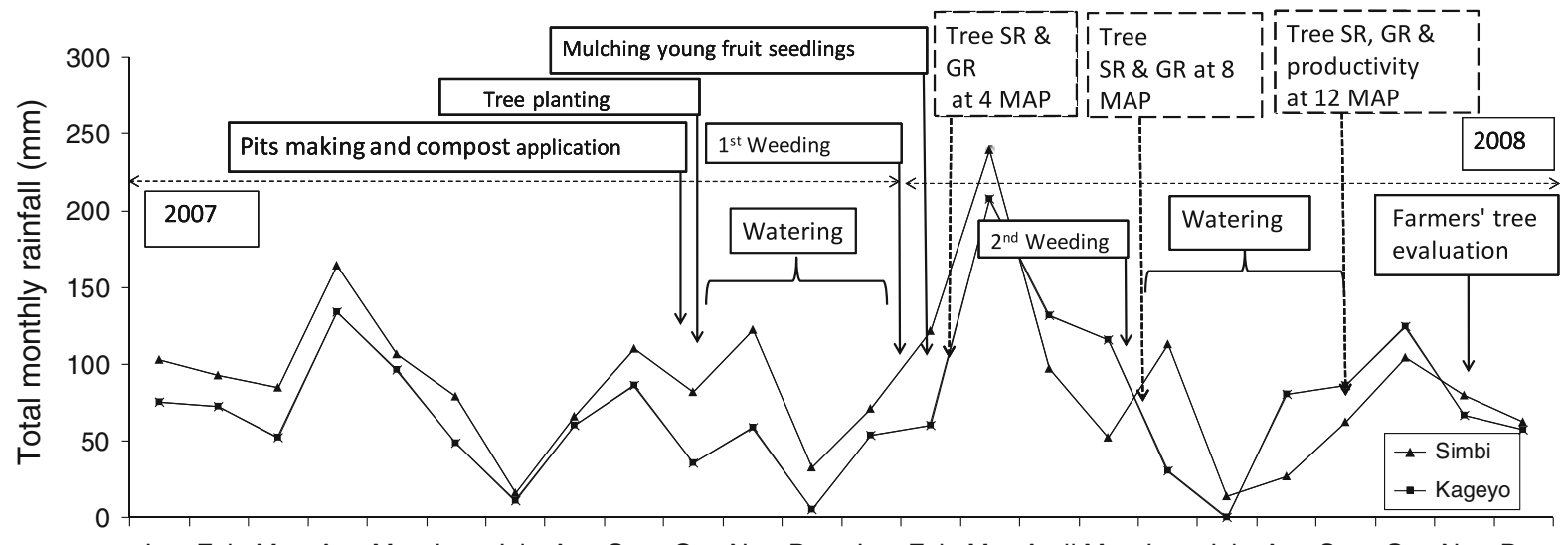

Jan Feb Mar Apr May June July Aug Sept Oct Nov Dec Jan Feb Mar April May June July Aug Sept Oct Nov Dec

Months

Fig. 1 Total monthly rainfall $(\mathrm{mm})$ and different tree management activities executed by farmers (solid squares) and tree evaluation activities by the researcher (dotted squares) in 2007and 2008 in Simbi and Kageyo. Total rainfall in 2007 was 1,061 and 734 mm in Simbi and Kageyo respectively. In 2008, it was 1,045 and $1,016 \mathrm{~mm}$ in both locations respectively. $S R \&$ $G R$ survival rate and growth measurement, MAP months after planting. Sources for rainfall data Ministry of Infrastructure/ Meteorological Unit, Rwanda (2009), unpublished data

Table 1 Main socioeconomic characteristics of households in Simbi and Kageyo

\begin{tabular}{|c|c|c|c|c|c|c|c|c|}
\hline & \multicolumn{4}{|c|}{ Simbi $(n=65)$} & \multicolumn{4}{|c|}{ Kageyo $(n=78)$} \\
\hline & $\begin{array}{l}\text { Wealthier } \\
(n=12)\end{array}$ & $\begin{array}{l}\text { Moderate } \\
(n=19)\end{array}$ & $\begin{array}{l}\text { Poor } \\
(n=34)\end{array}$ & Means & $\begin{array}{l}\text { Wealthier } \\
(n=11)\end{array}$ & $\begin{array}{l}\text { Moderate } \\
(n=25)\end{array}$ & $\begin{array}{l}\text { Poor } \\
(n=42)\end{array}$ & Means \\
\hline Family size & $6.6(0.8)$ & $5.9(1.1)$ & $4.5(1.8)$ & 5.6 & $6.0(2.3)$ & $6.1(1.8)$ & $4.7(2.0)$ & 5.6 \\
\hline $\begin{array}{l}\text { Education level }^{\mathrm{a}} \text { (\% HH heads } \\
\text { with basic education) }\end{array}$ & 66 & 47 & 37 & 40 & 66 & 34 & 18 & 26 \\
\hline Cattle owned (number) & $3.5(1.3)$ & $1.3(0.9)$ & - & 2.4 & $3.3(1.0)$ & $1.5(1.0)$ & - & 2.4 \\
\hline Livestock (number) & $7.4(3.7)$ & $4.5(3.3)$ & $1.2(1.0)$ & 4.3 & $5.6(2.5)$ & $3.6(1.3)$ & $2.2(1.0)$ & 4.1 \\
\hline Land size (ha) & $1.9(1.6)$ & $0.5(0.2)$ & $0.3(0.1)$ & 0.8 & $3.2(0.8)$ & $0.5(0.3)$ & $0.30(0.2)$ & 1.3 \\
\hline Area under woodlot/forest (ha) & $0.16(0.05)$ & $0.05(0.03)$ & $0.005(0.001)$ & 0.05 & $0.34(0.2)$ & $0.07(0.05)$ & $0.02(0.0)$ & 0.1 \\
\hline
\end{tabular}

Values in parentheses are standard deviation (SD)

${ }^{a}$ Household with basic education refers to a household who has at least completed primary school; the overall mean was calculated over the total sampled households per location

trees and shrubs. In the current study, we considered "a tree" based on the western epistemology, meaning woody and shrub vegetation excluding herbaceous species.

A formal survey was conducted with 65 farms in Simbi and 73 farms in Kageyo to identify which, where and to what extent different types of trees are currently grown on farm. The data were gathered separately for woodlots and croplands on individual farm types using a pre-tested and pre-coded questionnaire. Data included household characteristics such as farm identification and location, household status, education level, land area, the type and number of animals reared, and source of firewood. The second set of data related to farmer's preferences for specific species and their management. Since the local language (Kinyarwanda) was used during the interview, tree names were given in local names and translated into scientific names. Names were cross-checked with a tree expert from ISAR/Agroforestry Department. The frequencies of the presence of tree species were recorded and used a proxy for identifying the most preferred tree species that were selected afterward for tree testing. Species richness (i.e. the total number of 
trees species on farm and tree density (the total number of trees per unit area) were recorded.

Testing farmers' preferences

Farmers categorized into the three wealth categories were listed and 25 farmers per wealth group were selected based on a systematic sampling procedure by picking every second farmer on the list of farmers belonging to each wealth category. The trial was discontinued on 5 farms in Simbi and 3 farms in Kageyo due to various reasons including death, or farmers who had not planted any tree. A tree evaluation exercise was finally conducted with 20 farmers in Simbi and 22 farmers in Kageyo. Two species belonging to each of the most important tree classes were selected: timber trees (Eucalyptus urophyla, Grevillea robusta), legume shrubs (Calliandra calothyrsus and Tephrosia vogelii) and fruit trees (Persea americana and Citrus sinensis). Tree seedlings were obtained from the agroforestry nursery of the Rwanda Agricultural Research Institute, ISAR). Eucalyptus urophyla seedlings were supplied by ISAR (Rwanda Agricultural Research Institute/Forestry and Agroforestry Department). Grevillea, Calliandra and Tephrosia seeds were from Gisagara provenance (Southern Rwanda) and seedlings were produced by ISAR (Forestry and Agroforestry Department). Grafted fruit tree seedlings (Persea americana and Citrus sinensis) were produced and supplied by ISAR/ Rubona station (Horticultural Department). A total of 60 trees (10 Eucalyptus urophyla, 10 Grevillea robusta, 10 Calliandra calothyrsus and 10 Tephrosia vogelii, 10 Persea americana and 10 Citrus sinensis.) were made available to each farmer for planting. A total of 2,520 tree seedlings were distributed across the two locations. Seedlings were $15-25 \mathrm{~cm}$ height at planting time. Farmers were free to choose which tree species to plant and where to plant them. Before planting, best tree planting practices were discussed. Farmers were advised to plant in pits of about $40 \times 40 \times 40 \mathrm{~cm}$ and apply manure and watering regularly for best results. Tree seedlings were planted at the start of the rainy season in September 2007. Trees, especially those planted on contours and home fields were weeded when this was done for adjacent crops. Fruit trees were mostly planted under banana crops near home compounds and were mulched. Some farmers watered trees at planting when a drought occurred. The chronological sequence of different farmer activities is provided in Fig. 1.

Data collection

The number of trees effectively planted by each farmer was recorded after planting by counting the number of planted trees and expressing this as a percentage of the trees the farmer had received. Management practices were recorded and expressed in percentage of farmers that had conducted primary management practices for individual tree species. Height measurement was done using measuring poles. The tree survival rate and height were assessed at 4, 8 and 12 MAP (months after planting) in different tree niches on different farms. Only data at 12 MAP are reported. Assessment of productivity was limited to Eucalyptus urophyla, Grevillea robusta, Calliandra calothyrsus and Tephrosia vogelii since there was no fruit production recorded at 12 MAP. Tree productivity was expressed in terms of dry biomass of above-ground prunings, including leaves and twigs or sticks of or less than $2 \mathrm{~m}$ length. Tree species were carefully pruned and the fresh biomass was determined at 12 months after planting on a sample of 10 trees selected on each farm type and in each niche. Eucalyptus trees planted in woodlots were pruned and dry matter reported per unit area. For the tree species planted along contours or along paths, productivity per unit area was obtained by estimating the total biomass on $100 \mathrm{~m}$ contour length and squaring to estimate biomass on a per ha basis. To determine biomass dry matter content, a $1 \mathrm{~kg}$ sample of fresh leafy and twigs parts was collected for each species from the different farms and the average dry matter content determined after oven-drying at $103{ }^{\circ} \mathrm{C}$ to constant weight and weighted for dry matter content (Anderson and Ingram 1993).

A farmer evaluation was conducted through an inventory of the problems encountered during the tree testing exercise using a formal survey. The questionnaire used was designed after a focus group discussion with participant farmers. Farmers also evaluated the trees for a range of attributes. For this, a focus group discussion was conducted with farmers involved in the study together with randomly selected tree users (carpenters and charcoal makers) to identify key criteria farmers considered important for tree evaluation. Sampled farmers included a broad range of farmers: wealthier, moderate and poor farmers with both 
household sex groups fairly represented. Female households were $30-40 \%$ of the participants. A total of 70-80 farmers and other tree users were involved at each study location. Farmers used different criteria for different tree species. For timber species, criteria were the ability of the tree species to provide poles, straightness, tree diameter, compatibility with other crops and coppicing ability. For legume species, the palatability for livestock, the ability to supply poles, the ability to coppice and the compatibility with other crops were the most important criteria for both locations. Other criteria were specific to sites. For instance, the durability of fire (the ability of firewood to keep burning for longer period), was an important criterion for the evaluation of timber species while the ability to contribute to soil fertility improvement was an additional important criterion to evaluate legume species in Simbi. For fruit trees, farmers focused on branching ability, adaptability to the site and growth vigour. Fruit trees were also assessed based on the early growth performance. Based on these criteria, an evaluation sheet was designed and only farmers who had planted trees as part of the study were asked to assess tree species using a scoring technique (Franzel 2001). The technique involves moving seeds or stones among pockets to score tree species on a scale of $1-5$. In addition, an informal survey helped to assess the farmers' future plans for agroforestry.

\section{Data analysis}

Data on the number of tree species, total number of trees per farm and per unit area basis were subjected to ANOVA using the mixed model procedure with site, farm type and farm location as fixed factors and farm (site) as the random factor in the Genstat statistical package (GENSTAT 2009). Data on the number of trees planted expressed as percentage of the total trees received per species, tree management activities, growth and productivity and farmers' evaluation were presented as means over sites or tree species as no clear relationship with farmer resource status could be found.

\section{Results}

Tree species diversity and density

Tree species were more diversified in Simbi (4.5 tree species farm $^{-1}$ ) than in Kageyo (2.9 tree species farm $\left.^{-1}\right)$, and, were more diversified in cropland (6.2 tree species farm ${ }^{-1}$ ) than in woodlots (1.0 tree species farm $^{-1}$ ) (Table 2). There was a significant interaction between site and location for the number of tree species. The number of tree species farm ${ }^{-1}$ in woodlots was comparable in both sites with averages of 1.1 and 1.2 tree species farm ${ }^{-1}$ in Simbi and in Kageyo respectively, but was much greater in cropland in Simbi (7.8 tree species farm ${ }^{-1}$ ) than in Kageyo (4.6 tree species farm $\left.^{-1}\right)$. There was a significant interaction between site, location and farm types for the number of trees farm ${ }^{-1}$. The average number of trees on farm was comparable in woodlots and croplands in wealthier and moderate farms in Simbi. On average, 164 and 149 trees farm $^{-1}$ were recorded in woodlots and cropland respectively on wealthier farms and 135 and 105 trees farm $^{-1}$ in woodlot and cropland respectively on moderate farms. In Kageyo, the number of trees was significantly larger in woodlots than in croplands in wealthier and moderate farms. On average, wealthier farms had 709 and 125 trees farm ${ }^{-1}$ in woodlot and cropland, respectively, and moderate farms had 160 and 48 trees farm $^{-1}$ in woodlots and croplands, respectively. The interaction between site and farm type was significant for the number of trees per unit area. In both locations, poor farms had the largest number of trees $\mathrm{ha}^{-1}$ compared with wealthier and moderate farms.

Number of trees planted on different farms

Farmers from different wealth groups differed in their preferences for tree species. More timber trees (Grevillea robusta and Eucalyptus urophyla) were planted by wealthier and moderate farmers than poor farmers (Table 3). Wealthier farmers planted all Grevillea robusta (100\% of the trees they received) while moderate and poor farmers planted between 70 and $88 \%$. For Eucalyptus urophyla, wealthier farmers planted only $60 \%$ of the trees in Simbi and $70 \%$ in Kageyo. As for legume species, a higher percentage of Calliandra calothyrsus was planted by poor farmers in Simbi (88\% of seedlings received) than by moderate farmers $(70 \%)$ and wealthier farmers $(66 \%)$. In contrary, the largest proportion (95\%) of Calliandra calothyrsus shrub was planted on wealthier farms of Kageyo. In the fruit trees category, all (100\%) of the Persea americana and Citrus sinensis were planted in Simbi. In Kageyo, 60-70 \% of Persea americana and $30-70 \%$ of Citrus sinensis respectively were planted. 
Table 2 Tree diversity and density on farms from different wealth categories recorded during a formal survey in 2007 in Simbi and Kageyo

\begin{tabular}{|c|c|c|c|c|c|c|}
\hline Site $(\mathrm{S})$ & $\begin{array}{l}\text { Farm type } \\
(\mathrm{FT})\end{array}$ & $\begin{array}{l}\text { Sample } \\
\text { size }(n)\end{array}$ & $\begin{array}{l}\text { Location } \\
\text { (L) }\end{array}$ & $\begin{array}{l}\text { Number of tree } \\
\text { species }^{c}\left(\text { farm }^{-1}\right)\end{array}$ & $\begin{array}{l}\text { Number of } \\
\text { trees }\left(\text { farm }^{-1}\right)\end{array}$ & $\begin{array}{l}\text { Number of } \\
\text { trees }\left(\mathrm{ha}^{-1}\right)\end{array}$ \\
\hline \multicolumn{7}{|c|}{ Simbi $(n=65)$} \\
\hline & \multirow[t]{2}{*}{ Wealthier } & \multirow[t]{2}{*}{12} & Woodlot & $1.2^{\mathrm{a}}$ & $164^{\mathrm{a}}$ & $1025^{\mathrm{b}}$ \\
\hline & & & Cropland & $8.3^{\mathrm{c}}$ & $149^{\mathrm{a}}$ & $135^{\mathrm{a}}$ \\
\hline & \multirow[t]{2}{*}{ Moderate } & \multirow[t]{2}{*}{19} & Woodlot & $0.8^{\mathrm{a}}$ & $135^{\mathrm{a}}$ & $2700^{\mathrm{b}}$ \\
\hline & & & Cropland & $7.7^{\mathrm{c}}$ & $105^{\mathrm{a}}$ & $331^{\mathrm{a}}$ \\
\hline & \multirow[t]{2}{*}{ Poor } & \multirow[t]{2}{*}{34} & Woodlot & $1.3^{\mathrm{a}}$ & $99^{a}$ & $19800^{\mathrm{d}}$ \\
\hline & & & Cropland & $7.6^{\mathrm{c}}$ & $22^{\mathrm{a}}$ & $1743^{\mathrm{b}}$ \\
\hline \multicolumn{7}{|c|}{ Kageyo $(n=78)$} \\
\hline & \multirow[t]{2}{*}{ Wealthier } & \multirow[t]{2}{*}{11} & Woodlot & $1.7^{\mathrm{a}}$ & $709^{b}$ & $2085^{\mathrm{b}}$ \\
\hline & & & Cropland & $5.1^{\mathrm{b}}$ & $125^{\mathrm{a}}$ & $230^{\mathrm{a}}$ \\
\hline & \multirow[t]{2}{*}{ Moderate } & \multirow[t]{2}{*}{25} & Woodlot & $1.1^{\mathrm{a}}$ & $160^{\mathrm{a}}$ & $2286^{\mathrm{b}}$ \\
\hline & & & Cropland & $4.8^{\mathrm{b}}$ & $48^{\mathrm{a}}$ & $210^{\mathrm{a}}$ \\
\hline & \multirow[t]{2}{*}{ Poor } & \multirow[t]{2}{*}{42} & Woodlot & $0.9^{\mathrm{a}}$ & $130^{\mathrm{a}}$ & $6500^{c}$ \\
\hline & & & Cropland & $3.9^{\mathrm{b}}$ & $34^{\mathrm{a}}$ & $205^{\mathrm{a}}$ \\
\hline \multicolumn{7}{|l|}{$P$ values } \\
\hline $\mathrm{S}$ & & & & $<.001 * * *$ & $0.663^{\mathrm{NS}}$ & $0.373^{\mathrm{NS}}$ \\
\hline FT & & & & 0.437 & $<.001 * * *$ & $0.121^{\mathrm{NS}}$ \\
\hline $\mathrm{L}$ & & & & $<.001 * * *$ & $<.001 * * *$ & $<.001 * * *$ \\
\hline $\mathrm{S} * \mathrm{FT}$ & & & & $0.130^{\mathrm{NS}}$ & $0.101^{\mathrm{NS}}$ & $0.04 * *$ \\
\hline $\mathrm{S} * \mathrm{~L}$ & & & & $<.001 * * *$ & $0.004 * *$ & $0.30^{\mathrm{NS}}$ \\
\hline $\mathrm{FT}^{*} \mathrm{~L}$ & & & & $0.706^{\mathrm{NS}}$ & $0.118^{\mathrm{NS}}$ & $0.50^{\mathrm{NS}}$ \\
\hline $\mathrm{S} * \mathrm{FT} * \mathrm{~L}$ & & & & $0.516^{\mathrm{NS}}$ & $<.001 * * *$ & $0.89^{\mathrm{NS}}$ \\
\hline
\end{tabular}

$S$ site, FT farm type, $L$ location, NS not significant

*** $P<0.001$,** $P<0.05$

a,b Values within columns with the same letter are not significantly different at the $5 \%$ level

${ }^{c}$ In woodlots, only dominant Eucalyptus species were counted (the most commonly found were E. camalduleis Dehnh, E. globulus Labill, and E. saligna $\mathrm{Sm}$ ), hybrid species were excluded since they could not be recognised and differentiated

Number of trees planted in different niches and tree survival

Grevillea robusta was in most cases established on contours (Table 4). The number of Grevillea robusta on contours was the smallest on wealthier farms $(60 \%)$ in Simbi and largest on poor farms (89\% and $78 \%$ respectively in Simbi and Kageyo). Some 10-20 \% of Grevillea robusta were allocated to other niches (farm boundaries or along paths). The survival rate was much better on contours, an average of 57.5-100\% whereas it ranged from 44.9-72\% in other niches (Table 5). Eucalyptus sp. trees were exclusively established in woodlot on wealthier farms but allocated to different niches on moderate and poor farms, and mainly to niches away from the farm (along paths). The average survival rate of Eucalyptus urophyla was much higher in woodlots (60-65\%) and was the lowest (40-56\%) along paths. On wealthier farms, Calliandra calothyrsus shrubs were established on contours or alternatively along paths. On moderate and poor farms, they were generally established in niches close to the croplands (contours or farm boundaries). Calliandra calothyrsus survived best on contours (50-72\%) compared with other niches (30-40\%). Tephrosia vogelii was exclusively planted on contours in Kageyo but in Simbi $33 \%$ of the shrubs were established along paths on wealthier farms. Persea americana and Citrus sinensis were planted either in homefields or in food crop fields, but with more than $50 \%$ of trees close to homesteads. The survival rate for fruit trees was the largest in the homestead. 
Table 3 Percent of distributed trees planted in different farm types in Simbi and Kageyo

\begin{tabular}{|c|c|c|c|c|c|c|}
\hline & \multicolumn{3}{|c|}{ Simbi $(n=20)$} & \multicolumn{3}{|c|}{ Kageyo $(n=22)$} \\
\hline & $\begin{array}{l}\text { Wealthier } \\
(n=6) \\
\%\end{array}$ & $\begin{array}{l}\text { Moderate } \\
(n=6) \\
\%\end{array}$ & $\begin{array}{l}\text { Poor } \\
(n=8) \\
\%\end{array}$ & $\begin{array}{l}\text { Wealthier } \\
(n=5) \\
\%\end{array}$ & $\begin{array}{l}\text { Moderate } \\
(n=8) \\
\%\end{array}$ & $\begin{array}{l}\text { Poor } \\
(n=9) \\
\%\end{array}$ \\
\hline Grevillea robusta & 100 & 88 & 87 & 100 & 84 & 70 \\
\hline Eucalyptus urophyla & 60 & 70 & 36 & 70 & 70 & 100 \\
\hline Calliandra calothyrsus & 66 & 88 & 72 & 95 & 80 & 77 \\
\hline Tephrosia vogelii & 53 & 51 & 36 & 50 & 44 & 20 \\
\hline Persea americana & 100 & 100 & 100 & 70 & 73 & 62 \\
\hline Citrus sinensis & 100 & 100 & 100 & 76 & 31 & 30 \\
\hline
\end{tabular}

The $n=$ the number of farmers per category who planted different tree species in each location. Each farmer was given 10 tree seedlings of each tree species

Tree management practices

Farmers were selective in which of the management practices such as compost application at planting, watering and weeding they used with each species (Table 6). Weeding was the most common management practice for Eucalyptus urophyla and Grevillea robusta seedlings. About $90 \%$ and $62.5 \%$ of farmers weeded the seedlings of Eucalyptus urophyla in Simbi and Kageyo, respectively. The same practice was carried out by $78 \%$ and $95 \%$ of farmers on Grevillea robusta in Simbi and Kageyo respectively. Fruit trees received much more care. They benefited from compost application and were weeded and watered. Watering was more common in Simbi than in Kageyo. A smaller number of farmers applied compost on Persea americana in Kageyo. Weeding was the only management practice carried out for legume shrubs, but much more weeding was done with Calliandra calothyrsus than with Tephrosia vogelii. Calliandra calothyrsus is more valued than Tephrosia by farmers, Calliandra is fed to animals and provides stakes for climbing beans in the area. Tephrosia has less uses, mainly used as fish trap.

Height and biomass production

Tree growth and productivity did not differ significantly between wealth classes of farmers (Table 7). Grevillea robusta height was comparable in both sites and attained 4.4-4.5 $\mathrm{m}$ at 12 months after planting. The production was slightly larger in Simbi with $7.8 \mathrm{t} \mathrm{ha}^{-1}$ than in Kageyo with $7.3 \mathrm{t} \mathrm{ha}^{-1}$. Tree height and productivity of
Grevillea robusta was greater on contours compared to other niches. Eucalyptus trees were 4.1-5.5 m high in woodlots with DM production much larger in Simbi $\left(9.2 \mathrm{t} \mathrm{ha}^{-1}\right)$ than in Kageyo $\left(7.1 \mathrm{t} \mathrm{ha}^{-1}\right)$. Eucalyptus trees planted along paths exhibited slow growth and hardly reached $2.5 \mathrm{~m}$ in both sites. The associated productivity was in the range of $2-4 \mathrm{t} \mathrm{ha}^{-1}$. Generally, growth and production of Calliandra calothyrsus was much better on contours than in other niches. Productivity of Calliandra calothyrsus on contours was two and three times greater compared to that along paths in Simbi and Kageyo, respectively. In Simbi, Tephrosia vogelii grew faster on contours with an average of $3.0 \mathrm{~m}$ at 12 months after planting as compared to $2.8 \mathrm{~m}$ high along paths. Tree height was closely related to the total lopped biomass with a linear relationship with a correlation coefficient greater than $50 \%$ for all the tree species (Fig. 2). The relationship was much stronger in Eucalyptus urophyla $\left(R^{2}=0.69\right)$ than in other species, and was weakest in Grevillea robusta $\left(R^{2}=0.51\right)$.

\section{Farmers' tree evaluation}

The constraints that the farmers identified were aggregated into major categories (Table 8). For timber trees, major constraints were termite damage, competition with Pennisetum spp., water stress, poor adaptation and animal browsing. Termite damage on Eucalyptus urophyla trees was reported in Simbi but not in Kageyo. Water stress was reported as a serious constraint to Eucalyptus urophyla establishment by $39 \%$ of farmers in Simbi and $50 \%$ in Kageyo. Only $17 \%$ of farmers in Simbi and $21 \%$ in Kageyo 
Table 4 Percent of trees planted in different farm locations by farm types in Simbi and Kageyo

\begin{tabular}{|c|c|c|c|c|c|c|}
\hline & \multicolumn{3}{|c|}{ Simbi $(n=20)$} & \multicolumn{3}{|c|}{ Kageyo $(n=22)$} \\
\hline & $\begin{array}{l}\text { Wealthier } \\
(n=6) \\
(\%)\end{array}$ & $\begin{array}{l}\text { Moderate } \\
(n=6) \\
(\%)\end{array}$ & $\begin{array}{l}\text { Poor } \\
(n=8) \\
(\%)\end{array}$ & $\begin{array}{l}\text { Wealthier } \\
(n=5) \\
(\%)\end{array}$ & $\begin{array}{l}\text { Moderate } \\
(n=8) \\
(\%)\end{array}$ & $\begin{array}{l}\text { Poor } \\
(n=9) \\
(\%)\end{array}$ \\
\hline \multicolumn{7}{|l|}{ G. robusta } \\
\hline Along paths & - & - & - & 40 & - & 21.7 \\
\hline Farm limits & 40 & 20 & 10.5 & - & 40 & - \\
\hline Contours & 60 & 80 & 89.5 & 60 & 60 & 78.3 \\
\hline \multicolumn{7}{|l|}{ E. urophyla } \\
\hline Along paths & - & 40 & 18.5 & - & - & 50 \\
\hline Contours & - & - & - & - & - & - \\
\hline Woodlot & 100 & 60 & 81.5 & 100 & 100 & 50 \\
\hline \multicolumn{7}{|l|}{ C. calothyrsus } \\
\hline Along paths & 25 & - & - & - & - & - \\
\hline Farm limits & - & - & 19.3 & - & 60 & - \\
\hline Contours & 75 & 100 & 80.7 & 100 & 40 & 100 \\
\hline \multicolumn{7}{|l|}{ T. vogelii } \\
\hline Along paths & 33 & - & - & - & - & - \\
\hline Contours & 67 & 100 & 100 & 100 & 100 & 100 \\
\hline \multicolumn{7}{|l|}{ P. americana } \\
\hline Homefield & 100 & 50 & 81.5 & 100 & 100 & 80.7 \\
\hline Food crop field & - & 50 & 18.5 & - & - & 19.3 \\
\hline \multicolumn{7}{|l|}{ C. sineis } \\
\hline Homefield & 51.7 & 57.2 & 87.9 & 80 & 75 & 85.7 \\
\hline Food crop field & 48.3 & 42.8 & 12.1 & 20 & 25 & 14.3 \\
\hline
\end{tabular}

The $n=$ the number of farmers per category who planted different tree species in each location. Each farmer was given 10 tree seedlings of each species

reported the same problem with Grevillea robusta. Pennisetum competition suppressing Grevillea robusta was reported by a large number of farmers of Simbi. Poor adaptation of Grevillea robusta was reported in $5 \%$ of cases in Kageyo. In fruit trees, major problems reported were water stress mainly reported in Kageyo (51\% of farmers), poor adaptation that was reported in 9-10\% of cases for Persea americana and 21-24\% of cases for Citrus sinensis. Damage due to animal browsing was reported by $12-15 \%$ of farmers for Persea americana and $23 \%$ of farmers for Citrus sinensis in Kageyo. For the legume species, major constraints reported were the poor adaptation in $13 \%$ of cases for Calliandra calothyrsus in Simbi and $17 \%$ of cases for Tephrosia vogelii in Kageyo. Water stress was reported in $14 \%$ of cases in Simbi, and in $42 \%$ and $54 \%$ of cases for
Calliandra calothyrsus and Tephrosia vogelii in Kageyo, respectively.

Farmer scoring and perspectives for tree planting

Farmer criteria for evaluating tree species were related to different tree attributes including growth patterns (straightness, trunk diameter, growth speed), tree productivity and product quality (poles, firewood and wood quality) and the compatibility with other crops (competition aspect) (Table 9). Eucalyptus urophyla was rated good to very good for the ability to provide poles. Grevillea robusta was rated good in Simbi but poor in Kageyo. The most striking differences in farmers' scores for Eucalyptus urophyla and Grevillea robusta were observed on tree compatibility with other crops and coppicing ability attributes. 
Table 5 Survival rate $(\%)$ of tree species planted in different farm locations in different farm types in Simbi and Kageyo

\begin{tabular}{|c|c|c|c|c|c|c|}
\hline & \multicolumn{3}{|c|}{ Simbi $(n=20)$} & \multicolumn{3}{|c|}{$\operatorname{Kageyo}(n=22)$} \\
\hline & $\begin{array}{l}\text { Wealthier } \\
(n=6) \\
(\%)\end{array}$ & $\begin{array}{l}\text { Moderate } \\
(n=6) \\
(\%)\end{array}$ & $\begin{array}{l}\text { Poor } \\
(n=8) \\
(\%)\end{array}$ & $\begin{array}{l}\text { Wealthier } \\
(n=6) \\
(\%)\end{array}$ & $\begin{array}{l}\text { Moderate } \\
(n=6) \\
(\%)\end{array}$ & $\begin{array}{l}\text { Poor } \\
(n=9) \\
(\%)\end{array}$ \\
\hline \multicolumn{7}{|l|}{ G. robusta } \\
\hline Along paths & - & - & - & 73.0 & - & 60 \\
\hline Farm limits & 44.9 & 50 & 50 & - & 53 & - \\
\hline Contours & 57.5 & 68.2 & 65 & 92.0 & 100 & 60.9 \\
\hline \multicolumn{7}{|l|}{ E. urophyla } \\
\hline Along paths & - & 56.4 & 40 & - & - & 48.8 \\
\hline Contours & - & - & - & - & - & - \\
\hline Woodlot & 65 & 66.1 & 65 & 62.1 & 60 & 55.0 \\
\hline \multicolumn{7}{|l|}{ C. calothyrsus } \\
\hline Along paths & 30 & - & - & - & - & - \\
\hline Farm limits & - & - & 40.0 & - & 31.6 & - \\
\hline Contours & 50 & 66.7 & 66.2 & 72 & 60.0 & 60.0 \\
\hline \multicolumn{7}{|l|}{ T. vogelii } \\
\hline Along paths & 20.6 & - & - & - & - & - \\
\hline Contours & 41.5 & 40.2 & 30.6 & 21.1 & 20.4 & 46.7 \\
\hline \multicolumn{7}{|l|}{ P. americana } \\
\hline Homefield & 100 & 73.2 & 80 & 80 & 66.7 & 70.6 \\
\hline Food crop field & - & 79.3 & 82 & - & - & 70 \\
\hline \multicolumn{7}{|l|}{ C. sineis } \\
\hline Homefield & 100 & 100 & 100 & 60.3 & 100 & 100 \\
\hline Food crop field & 87.5 & 80.8 & 93.7 & 50.0 & 66.7 & 72.2 \\
\hline
\end{tabular}

The $n=$ the number of farmers per category who planted different tree species in each location. Survival rate was calculated based on the number of trees that were effectively planted (Table 4)

Eucalyptus urophyla was rated poorly than Grevillea robusta on tree compatibility attribute and vice versa on coppicing ability. A large number of farmers showed interest in planting more Grevillea robusta in Simbi and Eucalyptus urophyla in Kageyo.

Fruit tree species were rated very well in Simbi but poorly in Kageyo with regards to the adaptability to different locations. Growth vigour was more highly rated in Simbi than in Kageyo. All farmers in Simbi and Kageyo expressed an interest to plant more Persea americana, while $80 \%$ of them interested in planting more Citrus sinensis. In the legume species category, Calliandra calothyrsus scored well for its ability to provide poles, palatability, coppicing and compatibility with other crops. In addition, Calliandra calothyrsus was rated good to very good for its potential to improve soil fertility. This attribute was only reported in Simbi probably due to trials that were previously conducted in the area. The overall appreciation of legume species indicated that farmers in both locations were much more interested to plant more Calliandra calothyrsus but especially so in Kageyo.

\section{Discussion}

Comparing socio-economic characteristics between the two locations

The average family size was comparable between similar farm types in the two locations (Table 1). The overall number of household heads with primary education level in moderate and poor farmer categories was larger in Simbi (40 \%) than Kageyo (26\%), but was comparable in wealthier category in the two areas. On average, 66, 47 and $37 \%$ of household heads in wealthier, moderate and poor farm categories, respectively, had basic education in Simbi while 66, 
Table 6 Primary management carried out by farmers (\% farmers) for different tree species during the tree testing in Simbi and Kageyo

\begin{tabular}{|c|c|c|c|c|}
\hline & \multicolumn{2}{|c|}{ Eucalyptus urophyla } & \multicolumn{2}{|l|}{ Grevillea robusta } \\
\hline & Simbi $(n=11)$ & Kageyo $(n=12)$ & Simbi $(n=14)$ & Kageyo $(n=22)$ \\
\hline None & - & 37.5 & 21.4 & 4.3 \\
\hline Watering & 10 & - & 14.3 & - \\
\hline Weeding & 90 & 62.5 & 64.3 & 95.7 \\
\hline \multirow[t]{3}{*}{ Compost application } & - & - & - & - \\
\hline & \multicolumn{2}{|l|}{ Persea americana } & \multicolumn{2}{|l|}{ Citrus sinensis } \\
\hline & Simbi $(n=19)$ & Kageyo $(n=22)$ & Simbi $(n=19)$ & Kageyo $(n=22)$ \\
\hline None & 5.7 & 5.0 & 5.0 & 4.9 \\
\hline Watering & 20.1 & 5.0 & 15.9 & - \\
\hline Weeding & 52.2 & 85 & 68.5 & 95.1 \\
\hline \multirow[t]{3}{*}{ Compost application } & 22 & 5.0 & 10.6 & - \\
\hline & \multicolumn{2}{|c|}{ Calliandra calothyrsus } & \multicolumn{2}{|c|}{ Tephrosia vogelii } \\
\hline & Simbi $(n=20)$ & $\operatorname{Kageyo}(n=20)$ & Simbi $(n=18)$ & $\operatorname{Kageyo}(n=6)$ \\
\hline None & 33.4 & 10 & 55.5 & 66.6 \\
\hline Watering & - & - & - & - \\
\hline Weeding & 66.6 & 90 & 44.5 & 33.4 \\
\hline Compost application & - & - & - & - \\
\hline
\end{tabular}

34 and $18 \%$ of household heads in the corresponding farm groups had the same education level in Kageyo. The average number of cattle reared was similar across farm types. On average, a wealthier farmer had 3 cattle and a moderate farmer 1 cow in both locations. However, wealthier and moderate farmers in Simbi had a larger number of livestock than farmers from similar resource groups in Kageyo. The average woodlot was larger on wealthier farms in Kageyo (0.34 ha) compared to the corresponding farm type of Simbi (0.16 ha). Agroforestry is more diversified in Simbi than in Kageyo. The reasons for differences in tree diversity are of biophysical and socio-economic nature (Table 2). The agro-ecological conditions, such as the altitude and temperature may have considerable influence on growth and development of different tree species. Higher altitude associated with low temperature limit the development of some tree species in the Buberuka Highlands, explaining why fruit trees such as papaya (Carica papaya) or mangoes (Mangifera indica) were not found there. The number of trees per farm differed between sites and wealth groups. Tree density was much higher on wealthier farms than on moderate and poor farms. This was mainly due to the large number of trees in woodlots and cropland on wealthier farms (Table 2). Wealthier farmers own larger farms (Table 1) and therefore have flexibility to plant a relatively larger number of trees in cropland. Woodlot/forest area was three to four times greater on wealthier farms than on moderate farms and twenty to thirty times more than on poor farms, contributing to a greater number of trees on farm (Table 1). The smaller number of tree species and density in Kageyo could also be related to the lower population density compared with Simbi. The population density was about 520 inhabitants per ha in Simbi (Huye DDP 2007) and 430 inhabitants per ha in Kageyo (Gicumbi DDP 2007). The high population density in Simbi may have contributed in increasing the tree density and diversity since specific tree species are needed for construction (Ficus thonninghi and Vernonia amygdalina used for fences around the house), daily needs (Vernonia, Erythrina abyssinica, Euphorbia tirucalli used as medicines) or to protect the inhabitants from danger (Erythrina). Despite having the least number of trees on per farm basis, resource-limited farms had the highest density of trees per unit area basis, confirming an inverse correlation between land holding size and 
Table 7 Height (m) and DM prunings (leafy and twigs) yield $\left(\mathrm{t} \mathrm{ha}^{-1}\right)^{\mathrm{a}}$ for different tree species at 12 months after planting in Simbi and Kageyo

Values in parentheses are
SD
a Yield for fruit species was
not assessed since there
were no fruits yet

tree density previously reported by den Biggelaar and Gold (1996) in Simbi.

Types and number of tree planted on farm and survival

In general, wealthier farmers planted most of the timber trees (Eucalyptus urophyla and Grevillea robusta). More Eucalyptus urophyla was planted in Kageyo (Table 3). A stronger preference for Eucalyptus urophyla by wealthier farmers was due to the fact that these farmers have a large woodlot area (Table 1) where Eucalyptus was exclusively established (Table 4). Poor farmers who did not have enough land for woodlots planted Eucalyptus urophyla trees in other niches. The strong preference for Grevillea robusta in Simbi was due to the fact that it is less competitive and may be grown in niches close to crops (e.g. contours) (Table 4). Also, Grevillea robusta is a fast growing tree producing relatively larger biomass and stakes with tolerance to poor degraded soils of southwest of Rwanda (König 1992). Grevillea robusta grew faster and produced slightly more biomass in Central plateau than in Buberuka, probably due to the limiting effect of cooler temperature at higher altitude (Kalinganire 1996).

The results indicated that legume shrubs were preferentially established on niches close to the home compounds (contours of cropland or farm boundaries) on moderate and poor farms while wealthier farmers allocated Calliandra calothyrsus to niches located further from the homestead such as along paths. The reasons that moderate and poor farmers chose niches closer to home compounds could be related to the importance they attach to Calliandra calothyrsus as an important source of firewood, stakes/poles and animal feeds. Based on our informal discussions with farmers, it appears that farmers prefer having Calliandra closer to cropping fields so that they may easily collect firewood sticks, stakes at the planting time and leafy biomass for animal feeding. In addition, Calliandra shrubs together with Grevillea robusta may offer possibility for soil conservation on sloping landscape threatened by severe soil erosion.Wealthier farms have several options including use of the large number of trees from the Eucalyptus urophyla woodlots.

The higher survival rate of fruit trees in homesteads was attributed to them being planted in more favourable growing conditions. Previous studies conducted in sub-Saharan Africa have shown that home fields are generally richer than fields further away from home. In most cases, both organic and inorganic fertilizers are preferably allocated to the fields closer to home compound at the expense of those located further away (e.g. Tittonell et al. 2005; Zingore et al. 2007). In addition, fruit trees grew under banana and benefited from shade, reduced evapo-transpiration and better soil moisture conditions. Fruit trees were regularly 
Fig. 2 Relationship between tree height and total DM aboveground prunings for Eucalyptus urophyla (a), Grevillea robusta (b), Calliandra calothyrsus and Tephrosia vogelii (d) established in Simbi and Kageyo in September 2007
Eucalyptus urophyla (a)

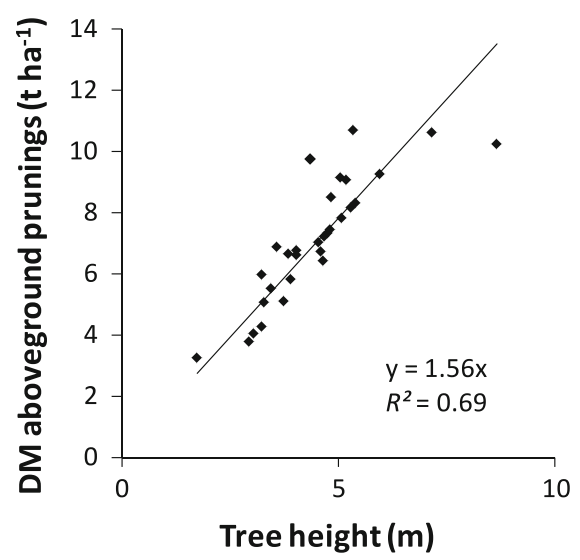

Calliandra calothyrsus (c)

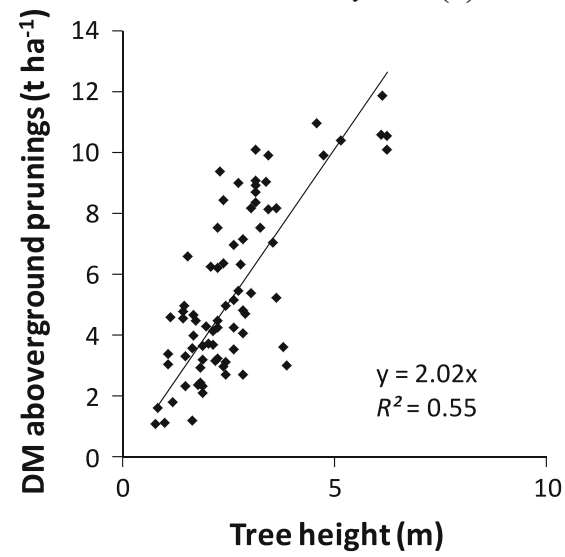

Grevillea robusta (b)

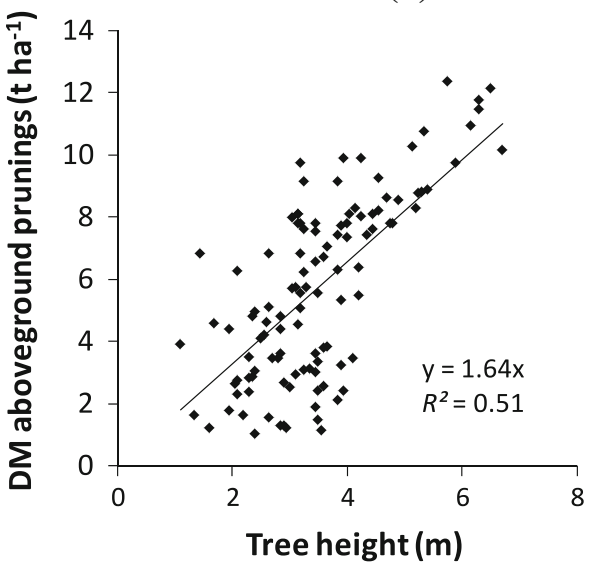

Tephrosia vogelii (d)

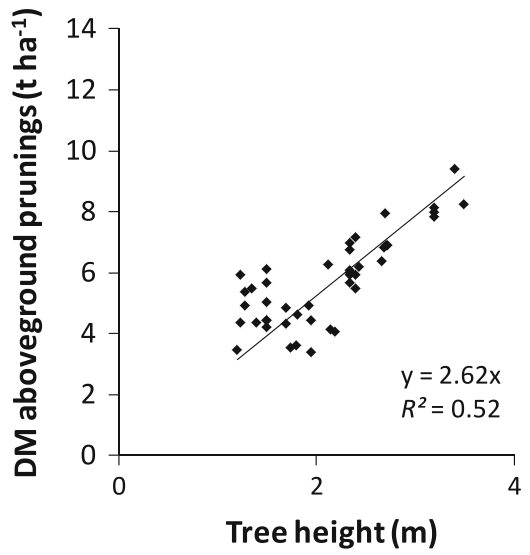

watered during the severe drought in September 2007 (Table 8). Fruit trees received more care than other tree species, indicating their importance for farmers. Farmer preferences for fruit species were also highlighted by the larger number of farmers willing to plant more of them on their farms (Table 9). Young fruit tree seedlings are less competitive than the fast growing timber trees (e.g. Eucalyptus sp, Table 9) so farmers can plant them in cropland (Table 4). More interest for Persea americana trees was also related to the possibility to use it for purposes other than fruit production. Some farmers without woodlots use all possible alternatives for firewood including old Persea americana trees. Farmers' strong preference for fruit trees was reported earlier in Rwanda (Balasubramanian and Egli 1986; Pinners and Balasubramanian 1991). Farmer investment in fruit trees appears to be common in low-input farming systems in tropical regions with similar biophysical configurations as Rwanda such as in Central Kenya highlands (Cleaver and Schreiber 1994). High-value trees including fruittree based agroforestry are popular in highland areas and play a complementary role with other activities in the subsistence farming system, contributing in increasing the total productivity and food security in the communities. Highland regions are known to have favourable climate conditions comparable to temperate conditions that would favour production of several fruit species that can be sold to other regions. This suggests that fruit species will continue to be one of the most preferred and planted tree species on resourcelimited farms in Rwanda. However, more research attention, access to planting material and fruit marketing development should be promoted to ensure that smallholder farmers benefit from the full potential of the fruit tree species. 
Table 8 Primary problems expressed by farmers (\% of farmers) during the tree species evaluation in Simbi and Kageyo

\begin{tabular}{|c|c|c|c|c|c|}
\hline & & \multicolumn{2}{|c|}{ Eucalyptus urophyla } & \multicolumn{2}{|l|}{ Grevillea robusta } \\
\hline & & Simbi $(n=11)$ & Kageyo $(n=12)$ & Simbi $(n=14)$ & Kageyo $(n=23)$ \\
\hline \multicolumn{2}{|l|}{ No problem } & 28 & 50 & 62 & 54 \\
\hline \multicolumn{2}{|l|}{ Termites } & 5 & - & 8 & - \\
\hline \multicolumn{2}{|c|}{ Competition for Pennisetum sp. } & - & - & 13 & 5 \\
\hline \multicolumn{2}{|l|}{ Water stress } & 39 & 50 & 17 & 21 \\
\hline \multicolumn{2}{|l|}{ Poor adaptation } & - & - & - & 5 \\
\hline \multicolumn{2}{|l|}{ Animal browsing } & 28 & - & - & 10 \\
\hline \multicolumn{2}{|l|}{ Soil compaction } & - & - & - & 5 \\
\hline & \multicolumn{3}{|c|}{ Persea americana } & \multicolumn{2}{|l|}{ Citrus sinensis } \\
\hline & \multicolumn{2}{|c|}{ Simbi $(n=17)$} & Kageyo $(n=22)$ & Simbi $(n=19)$ & Kageyo $(n=20)$ \\
\hline No problem & 40 & \multicolumn{2}{|c|}{28} & 79 & 36 \\
\hline Water stress & 35 & \multicolumn{2}{|c|}{51} & - & 17 \\
\hline Poor adaptation. & 10 & \multicolumn{2}{|c|}{9} & 21 & 24 \\
\hline \multirow[t]{3}{*}{ Animal browsing } & 15 & \multicolumn{2}{|c|}{12} & - & 23 \\
\hline & & \multicolumn{2}{|c|}{ Calliandra calothyrsus } & \multicolumn{2}{|l|}{ Tephrosia vogelii } \\
\hline & & Simbi $(n=20)$ & Kageyo $(n=20)$ & Simbi $(n=18)$ & Kageyo $(n=6)$ \\
\hline \multicolumn{2}{|l|}{ No problem } & 73 & 50 & 89 & 13 \\
\hline \multicolumn{2}{|l|}{ Poor adaptation } & 13 & - & - & 17 \\
\hline \multicolumn{2}{|l|}{ Water stress } & 14 & 42 & - & 54 \\
\hline \multicolumn{2}{|l|}{ Diseases } & - & - & 11 & 16 \\
\hline \multicolumn{2}{|l|}{ Animal browsing } & - & 4 & - & - \\
\hline \multicolumn{2}{|c|}{ Competition for Pennisetum sp. } & - & 4 & - & - \\
\hline
\end{tabular}

Tree growth and productivity

Better tree growth and productivity on contours (Table 7) could be attributed to several factors. Firstly, trees and shrubs established together with other crops may benefit from fertiliser and compost applied to these crops (Table 6). Secondly, the trees receive much more care since they are established closer to the home compound. Management practices such as weeding, watering were mostly done for trees established near homesteads or on contours and less for trees away from home. Trees planted on contours were planted at higher density (data not shown), resulting in more biomass production per unit area.

Generally, tree survival and productivity were much poorer than observed on the research station. For instance, the survival rate of Grevillea was
44-68 \% in southwest Rwanda, much lower than the average of $95.9 \%$ reported from on station trials in Ruhande (Kalinganire and Zuercher 1996). Calliandra calothyrsus hedges yielded $4-5.8 \mathrm{t} \mathrm{ha}^{-1}$ of biomass only half the $9.7 \mathrm{t}_{\text {year }}{ }^{-1} \mathrm{ha}^{-1}$ on experimental plots in southwest of Rwanda as reported by König (1992). Poor survival and productivity was partly due to the large variability among locations/niches where the trees were planted (Table 4), tree management (Table 6) and constraints faced during the tree establishment (Table 8). The strong linear relationship between tree growth and the above-ground productivity found with Eucalyptus urophyla $\left(R^{2}=0.69\right)$ was partly because most Eucalyptus urophyla trees were established in one niche (woodlot), which significantly reduced variability. The relationship between tree growth and biomass productivity may be used to estimate tree productivity on-farm. 
Table 9 Farmers' mean rating of species, using the Bao game ${ }^{\mathrm{a}}$, on criteria important to farmers and preferences for future planting, 12 months after planting (minimum and maximum values in parentheses)

\begin{tabular}{|c|c|c|c|c|}
\hline & \multicolumn{2}{|c|}{ Eucalyptus urophyla } & \multicolumn{2}{|l|}{ Grevillea robusta } \\
\hline & Simbi $(n=20)$ & Kageyo $(n=22)$ & Simbi $(n=20)$ & Kageyo $(n=22)$ \\
\hline Poles supply & $3.2(3-4)$ & $4.0(4-5)$ & $3.0(2-4)$ & $2.6(2-3)$ \\
\hline Straightness & $4.3(3-5)$ & $4.3(3-5)$ & $2.2(2-3)$ & $2.3(2-3)$ \\
\hline Trunk thickness & $4.7(4-5)$ & $4.0(3-5)$ & $3.0(2-4)$ & $3.2(3-4)$ \\
\hline Compatibility & $1.5(1-2)$ & $1.2(1-2)$ & $3.5(2-4)$ & $3.2(2-4)$ \\
\hline Coppicing & $4.0(3-5)$ & $3.3(2-4)$ & $1.5(1-2)$ & $1.6(1-2)$ \\
\hline Durability of fire & $4.9(4-5)$ & - & $2.3(2-3)$ & - \\
\hline Wood quality & - & $4.4(4-5)$ & - & $2.2(1-2)$ \\
\hline \multirow[t]{3}{*}{$\%$ farmers rating $4-5$ for future planting ${ }^{b}$} & 42.2 & 85.2 & 81.6 & 74.4 \\
\hline & \multicolumn{2}{|l|}{ Persea americana } & \multicolumn{2}{|l|}{ Citrus sinensis } \\
\hline & Simbi $(n=20)$ & Kageyo $(n=22)$ & Simbi $(n=20)$ & Kageyo $(n=22)$ \\
\hline Branching & $1.7(1-3)$ & $2.1(1-2)$ & $3.5(3-4)$ & $4.3(2-5)$ \\
\hline Adaptability & $4.2(3-5)$ & $1.9(1-3)$ & $4.0(3-5)$ & $2.0(2-3)$ \\
\hline Growth vigour & $2.3(2-3)$ & $1.9(1-2)$ & $3.8(3-4)$ & $2.1(2-3)$ \\
\hline Early growth & $3.8(2.4)$ & - & $2.0(1-3)$ & - \\
\hline Productivity & $4.4(4-5)$ & - & $2.1(1-3)$ & - \\
\hline \multirow[t]{3}{*}{$\%$ farmers rating $4-5$ for future planting } & 100 & 100 & 81.6 & 82.5 \\
\hline & \multicolumn{2}{|c|}{ Calliandra calothyrsus } & \multicolumn{2}{|l|}{ Tephrosia vogelii } \\
\hline & Simbi $(n=20)$ & Kageyo $(n=22)$ & Simbi $(n=20)$ & Kageyo $(n=22)$ \\
\hline Poles supply & $3.6(2-5)$ & $3.2(2-3)$ & $2.6(2-4)$ & $2.0(2-3)$ \\
\hline Palatability & $3.7(3-4)$ & $4.8(4-5)$ & $1.8(1-3)$ & $1.0(1-2)$ \\
\hline Coppicing & $3.6(3-4)$ & $4.1(3-5)$ & $1.9(1-3)$ & $1.6(1-2)$ \\
\hline Compatibility & $5.0(5-5)$ & $4.4(3-5)$ & $3.2(3-4)$ & $2.9(2-4)$ \\
\hline Soil fertility improvement & $3.9(3-5)$ & - & $1.2(1-2)$ & - \\
\hline$\%$ farmers rating $4-5$ for future planting & 80.2 & 95.8 & 28.3 & 11.1 \\
\hline
\end{tabular}

\footnotetext{
${ }^{a}$ Scale ranging from 1 to 5: 1: very low score, 2: low score, 3: high score, 4: very high score and 5: Best score
}

${ }^{b}$ Percent of farmers rating higher to very higher probably for a given species to be planted in future

Farmers' perceptions and perspectives for agroforestry

Farmers' scoring reflected farmers' perceptions on the main attributes and potential uses of different tree species. Tree utility and locational flexibility are important criteria for farmer preferences as earlier reported by den Biggelaar and Gold (1996). For instance Eucalyptus urophyla was the most preferred by wealthier farmers in Kageyo due to the fact that the species is used for several daily needs: firewood, construction, stakes, but also because farmers still have available land. In Simbi, on the other hand,
Eucalyptus urophyla was not among the most preferred species due to the critical land shortage (Tables 1 \& 9). All of the farmers planted Persea americana, although they already have many fruit species in the homestead niche. Farmers planted fruit trees in the food crop fields (Table 4) despite potential competition with food crops. A higher score for the ability to supply poles was expected for timber trees. However, Eucalyptus urophyla was blamed for its competitiveness (Table 9), a reason for the farmers planting it away from home for fear of competition with other food crops (Table 4). Farmer perceptions of Eucalyptus urophyla competitiveness were similar to 
that reported in western Kenya (Franzel et al. 2002). Calliandra calothyrsus was equally regarded as source of stakes and animal forage in Simbi (Table 9). In Kageyo, Calliandra calothyrsus scored well for the supply of poles but very high for palatability, suggesting a greater relative importance for livestock feeding compared with the staking of beans. Palatability was one of the important attributes used by farmers in the evaluation of tree forage. This criterion is related to the effect of feeds on animal nutrition (Roothaert and Franzel 2001). Calliandra biomass is given in smaller quantities (mostly a third of the diet) together with other feeds (e.g. grasses such as Setaria sp. or Pennisetum sp.).

Besides animal feeding, Calliandra calothyrsus is also appreciated for the supply of stakes for climbing bean. Climbing beans are widely grown in the highlands zone of Rwanda where they give about twice the yield of the local bush beans and are key for food security. One of the major challenges for bean production is the lack of staking material (den Biggelaar 1994, personal communication). Grevillea robusta, which is more adapted to the moderate and low altitude (Kalinganire 1996) and producing thicker sticks, is an alternative source of stakes for climbing beans.

Tephrosia was the least preferred species. Only $28 \%$ of the farmers in Simbi and $11 \%$ in Kageyo showed interest in growing it, which was related to the few uses they had for it. Tephrosia vogelii is used for catching fish or protecting stored grains against pest (Barnes and Freyre 1965). During our focus group discussion, it was observed that especially older farmers were more knowledgeable about Tephrosia vogelii and have been consistently using and managing it over a longer period of time. The species was tested by some farmers for feeding goats.

\section{Conclusion}

By using a variety of participatory approaches, we gained insight into the interest of farmers in different types of agroforestry that address a variety of their needs. The combination of surveys of existing practices, following farmers' preferences for planting and the way they managed different agroforestry species, as well as the farmers' own evaluations allowed us to identify on-farm niches for agroforestry for farmers of different wealth classes. Participatory approaches offer major advantages. First, they provide the opportunity for farmers to share their valuable knowledge of their agroforestry systems which can help to identify key opportunities, problems and constraints. Second, they allow researchers and farmers to jointly share results, to design agroforestry interventions and in doing so refine the development of agroforestry systems.

We found that farmers from different agro-ecological zones had preferences for different tree species. Tree performance (survival and growth) differed between the two agro-ecological zones. The tree management and performance appear to be similar across farm types, implying that farmers learn from each other.

Our results have important implications for setting priorities for future investment in agroforestry research. Fruit trees received little attention in the past research and development priority setting. The focus was largely on timber and legume species to deal with soil erosion and soil fertility problems (ICRAF/ ISAR/ECA 2001). Our results suggest that a revision of research priorities should consider extending attention to agroforestry species that match farmer preferences and include those options that have a direct potential for generating income. This fits with the current Government policy aimed at moving from subsistence to market-driven agriculture (MINAGRI 2009). Similarly, Calliandra calothyrsus, found to be popular with wealthier farmers owning dairy cattle appears to have a special role. Under the 'One cow, one poor farmer' programme, (a current government programme aimed at donating a cow to each vulnerable household), it is expected that the increasing number of dairy cattle will translate into a strong demand for quality feeds to maintain and increase milk production of cross-breed cattle. Calliandra calothyrsus prunings are a suitable feed for cross-bred cows (Tuwei et al. 2003) that have been widely-adopted in the highlands of East Africa (Wambugu et al. 2011). Whilst soil conservation and soil fertility remain to be important issues for agricultural development in the highlands of East and Central Africa, other entry points need to be sought for agroforestry-based approaches to these problems. For example, provision of staking material for climbing beans could be an entry point for introduction of multi-purpose legume trees into the farming system, which could provide multiple benefits. 
Acknowledgments We thank the Netherlands organization for cooperation in higher education (NUFFIC) for funding this study through NPT Grant (NPT/RWA/061). The National University of Rwanda and ISAR provided logistical support and tree seedlings. We gratefully acknowledge the assistance of Eric Gasana and Musabyimana Damascène, during the field data collection and the excellent collaboration of farmers from Simbi and Kageyo. Finally, we appreciate the valuable comments of two anonymous reviewers.

Open Access This article is distributed under the terms of the Creative Commons Attribution License which permits any use, distribution, and reproduction in any medium, provided the original author(s) and the source are credited.

\section{References}

Anderson JM, Ingram JSI (1993) Tropical soil biology and fertiliser: a handbook of methods. CAB International, Wallingford

Balasubramanian V, Egli A (1986) The role of agroforestry in the farming systems in Rwanda with special reference to the Bugesera-Gisaka-Migongo (BGM) region. Agroforest Syst 4:271-289

Balasubramanian V, Sekayange L (1992) La culture en couloirs dans le Bugesera au Rwanda. Effects des légumineuses arbustives sur l'évolution de la fertilité du sol et les performances des cultures vivrières. Note technique No8, ISAR/Rubona, Rwanda

Barnes DK, Freyre RH (1965) Recovery of natural insecticide from Tephrosia vogelii. II Toxicology properties of rotenoids extracted from fresh and oven-dried leaves. Econ Bot 20:279-287

Bene JG, Beall WH, Cote A (1977) Tree food and people-land management in the tropics. International Development and Research Centre, Ottawa

Cleaver KM, Schreiber GA (1994) Reversing the spiral; the population, agriculture and environment nexus in subSaharan Africa. World Bank, Washington

De Groote H, Rutto E, Odhiambo G, Kanampiu F, Khan Z, Coe R, Vanlauwe B (2010) Participatory evaluation of integrated pest and soil fertility management options using ordered categorical data analysis. Agroforest Syst 103: 233-244

den Biggelaar C (1994) Farmer knowledge and experimentation with trees and tree cultivation in agroforestry systems in Rwanda. PhD Dissertation. Department of Forestry, Michigan States University, East Lansing

den Biggelaar C, Gold MA (1995) The use and value of multiple methods to capture the diversity of endogenous agroforestry knowledge: an example from Rwanda. Agroforest Syst 30:263-275

den Biggelaar C, Gold MA (1996) Development of utility and location indices for classifying agroforestry species: the case of Rwanda. Agroforest Syst 34:229-246

Djimde M (1988) Potentiel agroforestier dans les systèmes d'utilisation des sols des hautes terres d'Afrique de l'Est à régime pluviométrique biomodal. Rapport AFRENA, 1. ICRAF, Nairobi

Franzel S (2001) Use of an indigenous board game, 'bao' for assessing farmers' preferences among alternative agricultural technologies. In: Franzel S, Scherr SJ (eds) Trees on the farm. Methods for assessing agroforestry adoption potential. CAB Publishing in association with ICRAF, Nairobi, pp 11-35

Franzel S, Ndufa JK, Obony OC, Bekele TE, Coe R (2002) Farmer-designed agroforestry trials: farmers' experiences in Western Kenya. In: Franzel S, Scherr SJ (eds) Trees on the farm. Assessing the adoption potential of agroforestry practices in Africa. CAB Publishing in association with ICRAF, Nairobi, pp 89-110

GENSTAT (2009) GENSTAT release 7.22 discovery edition 3, VSN International Ltd. Lawes Agricultural Trust, Rothamsted Experimental Station, Hertfordshire, England, UK

Gicumbi DDP (2007) Gicumbi district development plan 2008-2012, Gicumbi. Republic of Rwanda

Giller KE, Rowe EC, de Ridder N, van Keulen H (2006) Resource use dynamics and interactions in the tropics: scaling up in space and time. Agroforest Syst 88:8-27

Grandin B (1988) Wealth ranking in smallholder communities: a field manual. Intermediate Technology Development Group, Rugby

Huye DDP (2007) Huye district development plan 2008-2012, Butare. Republic of Rwanda

ICRAF/ISAR/ECA (2001) National workshop on agroforestry research and development strategic plan. Building and strengthening partnerships for scaling up the impact of agroforestry research and development. Kigali, Rwanda, pp $25-45$

Kalinganire A (1996) Performance of Grevillea robusta in plantations and on farms under varying environmental conditions in Rwanda. For Ecol Manag 80:279-285

Kalinganire A, Zuercher E (1996) Provenance trials of Grevillea robusta: interim results. In: Harwood CE (ed) Grevillea robusta in agroforestry and forestry. Proceedings of an international workshop, ICRAF

Kang BT, Wilson GF, Sipkens L (1981) Alley cropping maize and Leucaena leucocephala Lam. in Southern Nigeria. Plant Soil 63:165-179

King KFS (1989) The history of agroforestry. In Nair PKR (Ed) Agroforestry Systems in the tropics, vol. 31. Kluwer Academic Publishers in collaboration with ICRAF, The Netherlands, pp 3-11

König D (1992) The potential of agroforestry methods for erosion control in Rwanda. Soil Technol 5:167-176

Mercer DE, Miller RP (1998) Socioeconomic research in agroforestry: progress, prospects, priorities. Agroforest Syst 38:177-193

MINAGRI (2009) Strategic plan for transformation of agriculture in Rwanda—phase II (PSTA II). Final report. Ministry of Agriculture and Animal Resources, Kigali, Rwanda

Nair PKR (1998) Directions in tropical agroforestry research: past, present, and future. Agroforest Syst 38:223-245

Ndiaye SM, Sofranko AJ (1994) Farmers' perception of resources problems and adoption of conservation practices in a densely populated area. Agr Ecosyst Environ 48:35-47 
Niang AI, Styger E (1990) Les Systèmes d'utilisation des Terres et Leur Potentiel Agroforestier au Rwanda. In : Niang AI, Gahamanyi A, Styger E (eds) Actes de la Première Réunion Agroforstière par le Projet ICRAF/ISAR du 13 au 15/9/ 1990 à Kigali. AFRENA Report 36. ICRAF. Butare, Rwanda

Niang AI, Styger E, Gahamanyi A, Hoekstra D, Coe R (1998) Fodder-quality improvement through contour planting of legume-shrub/grass mixture in croplands of Rwanda highlands. Agroforest Syst 39:263-274

Ojiem JO, de Ridder N, Vanlauwe B, Giller KE (2007) Socioecological niche: a conceptual framework for integration of legumes in smallholder farming systems. Int J Agric Sustain 4:79-93

Paterson RT, Karanja GM, Nyaata OZ, Kariuki IW, Roothaert RL (1998) A review of tree fodder production and utilisation within smallholder agroforestry systems in Kenya. Agroforest Syst 41:181-199

Pinners E, Balasubramanian V (1991) Use of iterative diagnosis and design approach in the development of suitable agroforestry systems for a target area. Agroforest Syst 15:183-201

Raintree JB (1983) Strategies for enhancing the adoptability of agroforestry innovations. Agroforest Syst 1:173-187

Roothaert RL, Franzel S (2001) Farmers's preferences and use of local fodder trees and shrubs in Kenya. Agroforest Syst 52:239-252

Sanchez PA (1995) Science in agroforestry. Agroforest Syst 30:5-55

Tittonell P, Vanlauwe B, Leffelaar PA, Shepherd KD, Giller KE (2005) Exploring diversity in soil fertility management of smallholder farms in western Kenya. I. Heterogeneity at region and farm scale. Agr Ecosyst Environ 110:149-165

Tuwei PK, Kang'ara JNN, Mueller-Harvey I, Poole J, Ngugi FK, Stewart JL (2003) Factors affecting biomass production and nutritive value of Calliandra calothyrsus leaf as fodder for ruminants. J Agric Sci 141:113-127

Verdoodt A (2002) Elaboration and Application of an adjusted agricultural land evaluation model for Rwanda, $\mathrm{PhD}$ dissertation, vol I. Ghent University, Belgium

Wambugu C, Place F, Franzel S (2011) Research, development and scaling-up the adoption of fodder shrub innovations in East Africa. Int J Agric Sustain 9:100-109

Wilson GF, Kang BT (1981) Developing stable and productive biological cropping system for the humid tropics. In: Stonehouse B (ed) Biological husbandry. A scientific approach to organic farming. Butterworth, London, pp 193-203

Yamoah CF, Burleigh JR (1990) Alley cropping Sesbania sesban (L.) Merill with food crops in the highland region of Rwanda. Agroforest Syst 10:169-181

Yamoah CF, Grosz R, Nizeyimana E (1989) Early growth of alley shrubs in the Highland region of Rwanda. Agroforest Syst 9:171-184

Young A (1997) Agroforestry for soil management, 2nd edn. $\mathrm{CAB}$ International in Association with the International Centre for Research in Agroforestry, Wallingford

Zingore S, Murwira HK, Delve RJ, Giller KE (2007) Influence of nutrient management strategies on variability of soil fertility, crop yields and nutrient balances on smallholder farms in Zimbabwe. Agr Ecosyst Environ 119:112-126 